\title{
Ractopamine concentration on the lipid profile of swine fat and meat
}

\author{
Stephan Alexander da Silva Alencar ${ }^{1}{\text { Charles } \text { Kiefer }^{1 *}}^{*}$ \\ Karina Márcia Ribeiro de Souza Nascimento ${ }^{1}$ \\ Luiz Henrique Viana ${ }^{2}$ Liliane Maria Piano Gonçalves ${ }^{1}$ Gabriel Cipriano Rocha ${ }^{3}$ \\ Anderson Corassa ${ }^{4}$ Rodrigo Caetano de Abreu ${ }^{1}$
}
'Programa de Pós-graduação em Ciência Animal, Faculdade de Medicina Veterinária e Zootecnia, Universidade Federal de Mato Grosso do Sul (UFMS), 79070-900, Campo Grande, MS, Brasil. E-mail: charles.kiefer@ufms.br. "Corresponding author. ${ }^{2}$ Instituto de Química, Universidade Federal de Mato Grosso do Sul (UFMS), Campo Grande, MS, Brasil. ${ }^{3}$ Universidade Federal de Viçosa (UFV), Viçosa, MG, Brasil.
${ }^{4}$ Universidade Federal de Mato Grosso (UFMT), Sinop, MT, Brasil.

ABSTRACT: This study was conducted to evaluate the effect of ractopamine concentrations on swine fat and meat lipid profiles. Ninety finishing barrows, initially weighing $71.9 \pm 4.4 \mathrm{~kg}$, were distributed in a randomized block design in three ractopamine concentrations $(0,10$ and 20ppm) with fifteen replicates of two animals in each. Gas chromatography was used to analyze the lipid profiles of backfat and meat. The inclusion of ractopamine in the diet changed $(P<0.05) \alpha$-linolenic acid and eicosatrienoic acid concentrations in the backfat but did not affect $(P>0.05)$ any of the other fatty acids or indexes evaluated. In the meat, a significant effect $(P<0.05)$ was observed on nine fatty acids evaluated, with a decrease $(P<0.05)$ in lauric, myristic, and palmitic fatty acids, and an increase $(P<0.05)$ in linoleic, $\gamma$-linolenic, dihomo- $\gamma$-linolenic, and eicosapentaenoic acid. Ractopamine also affected $(P<0.05)$ the concentration of $\alpha$-linolenic and arachidonic acid in the meat $(P<0.05)$. The indexes evaluated were also affected $(P<0.05)$. Addition of 10 ppm decreased the saturated fatty acid concentration, atherogenic index, thrombogenic index and omega 6: omega 3, while it increased unsaturated and polyunsaturated fatty acids concentrations. Ractopamine addition had less effect on the backfat than on the meat, and the 10ppm level improved the meat lipid profile.

Key words: backfat, fatty acids, pork.

Concentração da ractopamina sobre o perfil lipídico da gordura e carne suína

RESUMO: Este estudo foi conduzido para avaliar o efeito das concentrações de ractopamina no perfil lipídico da gordura e carne suína.

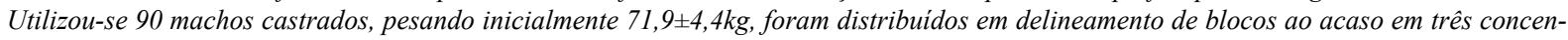
trações de ractopamina (0, 10 e 20ppm), com quinze repetições e dois animais por unidade experimental. Foi utilizada cromatografia gasosa para analisar os perfis lipídicos da gordura subcutânea e da carne. A inclusão de ractopamina na dieta alterou $(P<0,05)$ os níveis dos ácidos graxos $\alpha$-linolenico e eicosatrienoico na gordura subcutânea e não afetou $(P>0,05)$ nenhum dos outros ácidos graxos ou índices avaliados. Em relação à gordura da carne, houve efeito $(P<0,05)$ sobre nove ácidos graxos avaliados, com redução $(P<0,05)$ dos ácidos graxos láurico, mirístico e palmítico, e aumento $(P<0,05)$ do linoleico, $\gamma$-linolênico, dihomo- $\gamma$-linolênico e eicosapentaenoico. A ractopamina também afetou $(P<0,05)$ a concentração do linolênico e araquidônico na carne. Os índices avaliados também foram afetados $(P<0,05)$. A inclusão de $10 p p m$ diminuiu a concentração dos ácidos graxos saturados, índice aterogênico, índice trombogênico e ômega 6: ômega 3, e aumentou a concentração dos ácidos graxos insaturados e poli-insaturados. A inclusão de ractopamina teve menor efeito na gordura subcutânea do que na carne, sendo que o nível de 10ppm melhorou o perfil lipidico da carne.

Palavras-chave: ácidos graxos, toucinho, carne suína.

\section{INTRODUCTION}

Themeat processingindustryhas soughtlowerfat and higher-meat carcasses, rewarding producers with the most suitable carcasses, and consequently stimulating new nutritional strategies in the field (CORASSA et al., 2010). One way to improve production efficiency and pig carcass quality has been the use of different additives (CANTARELLI et al., 2009).

Among the used additives, ractopamine has been the most studied. It is a phenethanolamine derivative with a structure analogous to catecholamines. Ractopamine acts by redistributing nutrients and altering the cellular metabolism, thus improving the performance and efficiency of the pigs (APPLE et al., 2007).

In addition to effects on the performance of pigs, ractopamine also affects their meat distribution, with $20 \mathrm{ppm}$ ractopamine producing a greater loin-eye area and a higher percentage of lean meat than other ractopamine concentrations used (KIEFER \& SANCHES, 2009). Ractopamine also reduces fat deposition in the carcass, by reducing lipogenesis and 
increasing lipolysis, which are its main mechanism of action (FERREIRA et al., 2013).

Ractopamine has been shown to effectively reduce carcass fat amount (APPLE et al., 2007; CANTARELLI et al., 2009; CORASSA et al., 2010), which has provided economic benefits (BRUMATTI $\&$ KIEFER, 2010). However, its qualitative effect on fat has not been extensively investigated; although, the fatty acid profile of swine fat is known to be modified through different diets (DURAN-MONTGÉ et al., 2010). Several studies have evaluated various diets and observed changes in the swine fatty acid profile (CARR et al., 2005; KIM et al., 2014; GOIS et al., 2017).

Regarding ractopamine, a few studies have been conducted and have identified its potential use in altering the deposited fat profile (ENGESETH et al., 1992; WIEGAND et al., 2011). Results are contradictory with some studies not showing a significant difference in fat profile (WEBER et al., 2006; WATANABE et al., 2012), while others observed differences for some fatty acids (ENGESETH et al., 1992; PERKINS et al., 1992; CARR et al., 2005). Furthermore, older studies evaluated fewer fatty acids, providing limited knowledge into the fatty acid profile.

Identifying ractopamine's effect on deposited fatty acids is important because of consumer's increased health concern and desire to know more about the product (JAKOBSEN et al., 2009). The objective of this study was to evaluate the lipid profile of swine fat and meat from animals fed with different ractopamine concentrations.

\section{MATERIALS AND METHODS}

Ninety genetically similar finishing barrows were used, with mean initial weights ranging from $71.9 \pm 4.4 \mathrm{~kg}$ to $96.9 \pm 6.3 \mathrm{~kg}$. Animals were distributed in a randomized block design, in three ractopamine concentrations $(0,10$ and 20ppm) with fifteen replicates, and two animals in each experimental unit. Initial weights were considered during blocks formation. The installation consisted of a masonry shed with ceramic tiles. The pens had bell drinkers and semi-automatic feeder, which provided feed and water ad libitum.

Formulation of the experimental diets (Table 1) met the nutritional requirements proposed by ROSTAGNO et al. (2011) for barrows between 70 to $100 \mathrm{~kg}$ of basal weight (BW) with a high genetic potential. The experimental diets were soybean meal and corn-based. Ractopamine was added to replace kaolin.

The animals were fasted for eight hours and were transported to the slaughter plant. Samples of the Longissimus dorsi muscle with adipose tissue were obtained at the point P2 (region of insertion at the last thoracic vertebra with the first lumbar vertebra, six centimeters from the dorsal line).

Lipids were extracted and methylated according the technique adapted from HARA \& RADIN (1978). For lipid extraction, 5g of muscle and $1.5 \mathrm{~g}$ of backfat were collected and added to a $3: 2$ hexane:isopropanol mixture. For methylation, 40mg of the extracted lipid was weighed and mixed with methyl acetate, sodium methoxide ( $30 \%$ methanol) and anhydrous oxalic acid.

Separation and identification of fatty acids were performed using a Varian CP-3800 gas-liquid chromatograph equipped with a flame ionization detector (FID), "split/splitless" injector, in fused silica capillary column $(30 \mathrm{~m} \times 0.25 \mathrm{~mm})$ with BPX70 (70\% Cyanopropyl polysilphenylene-siloxane).

Chromatographic conditions were as follows: an initial column temperature of $80^{\circ} \mathrm{C}(2 \mathrm{~min})$, then increased to $220^{\circ} \mathrm{C}(10 \mathrm{~min})$ at $4^{\circ} \mathrm{C} \mathrm{min}^{-1}$. The carrier gas was helium $\left(1.0 \mathrm{ml} \mathrm{min}^{-1}\right)$, and the detector gases were synthetic air and hydrogen, with nitrogen as a "makeup" gas. Fatty acids were identified by comparing their retention times to those of a standard mixture (FAME mix, 100mg, 37 components). Fatty acids were expressed as a percentage of total fatty acids identified.

The following two equations, adapted from a study by ULBRICHT \& SOUTHGATE (1991), were used to measure the quality of fat via atherogenic index (AI) and thrombogenic index (TI), where MUFA stands for monounsaturated fatty acid: $\mathrm{AI}=$ Lauric acid $+(4 \mathrm{x}$ Myristic acid) + Palmitic acid/ (Omega 6 + Omega 3 + MUFA); $\mathrm{TI}=$ Myristic acid + Palmitic acid + Stearic acid/ $((0.5$ $\mathrm{x}$ Oleic acid $)+(0.5 \mathrm{x}$ MUFA $)+(0.5 \mathrm{x}$ Omega 6$)+(3 \mathrm{x}$ Omega 3) + Omega 3: Omega 6). Data were analyzed by the PROC GLM procedure through Statistical Analyses System (SAS) software, with a 5\% of significance value. Mean values were analyzed by the Tukey test.

\section{RESULTS AND DISCUSSION}

The most considerable ractopamine effects were seen in the meat rather than in the backfat, a result similar to those previously reported (ENGESETH et al., 1992; PERKINS et al., 1992). Ractopamine concentrations influenced backfat concentrations of $\alpha$-linolenic and eicosatrienoic fatty acids, where $10 \mathrm{ppm}$ of ractopamine provided higher fatty acid concentrations $(\mathrm{P}<0.05)$ than diets with 0 and 20ppm, which did not differ between each other (Table 2). However, ractopamine did not affect any of the other evaluated fatty acids $(\mathrm{P}>0.05)$.

Only the $\alpha$-linolenic and eicosatrienoic fatty acids had altered concentrations in backfat, while 
Table 1 - Nutritional and centesimal composition of experimental diets.

\begin{tabular}{|c|c|c|c|}
\hline \multirow{2}{*}{ Ingredients } & \multicolumn{3}{|c|}{ 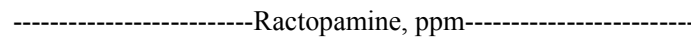 } \\
\hline & 0 & 10 & 20 \\
\hline Corn & 70.150 & 70.150 & 70.150 \\
\hline Soybean meal, $46,5 \%$ & 20.444 & 20.444 & 20.444 \\
\hline Soybean oil & 3.394 & 3.394 & 3.394 \\
\hline Dicalcium phosphate & 0.832 & 0.832 & 0.832 \\
\hline Limestone & 0.445 & 0.445 & 0.445 \\
\hline Vit. and min. supplement ${ }^{1}$ & 0.100 & 0.100 & 0.100 \\
\hline Sodium chloride & 0.305 & 0.305 & 0.305 \\
\hline L-Lysine $\mathrm{HCl}$ & 0.451 & 0.451 & 0.451 \\
\hline DL-Methionine & 0.159 & 0.159 & 0.159 \\
\hline L-Threonine & 0.177 & 0.177 & 0.177 \\
\hline L-Tryptophan & 0.037 & 0.037 & 0.037 \\
\hline Ractopamine & 0.000 & 0.050 & 0.100 \\
\hline Inert matter (kaolin) & 3.506 & 3.456 & 3.406 \\
\hline \multicolumn{4}{|c|}{ 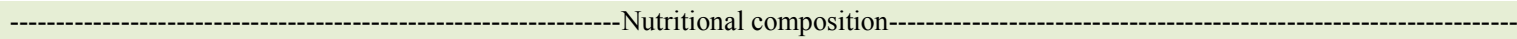 } \\
\hline Crude protein, $\%$ & 16.00 & 16.00 & 16.00 \\
\hline Net Energy, Kcal kg ${ }^{-1}$ & 2,550 & 2,550 & 2,550 \\
\hline Metabolizable Energy, Kcal kg-1 & 3,327 & 3,327 & 3,327 \\
\hline Digestible lysine, \% & 1.000 & 1.000 & 1.000 \\
\hline Digestible met.+cyst., $\%$ & 0.617 & 0.617 & 0.617 \\
\hline Digestible threonine, $\%$ & 0.667 & 0.667 & 0.667 \\
\hline Digestible tryptophan, \% & 0.187 & 0.187 & 0.187 \\
\hline Digestible valine, $\%$ & 0.638 & 0.638 & 0.638 \\
\hline Calcium, $\%$ & 0.484 & 0.484 & 0.484 \\
\hline Available phosphorus, $\%$ & 0.248 & 0.248 & 0.248 \\
\hline Sodium, $\%$ & 0.160 & 0.160 & 0.160 \\
\hline
\end{tabular}

${ }^{1}$ Quantity per kilogram of diet: vitamin A - 1,250 IU; vitamin D3 - $250 \mathrm{IU}$; vitamin E - 6.25 IU; vitamin K3 - $0.75 \mathrm{mg}$; vitamin B1 $0.375 \mathrm{mg}$; vitamin B2 - 1mg; vitamin B6 - 0.375mg; vitamin B12 - 4.5mcg; niacin - 4.5mg; pantothenic acid - 2.3mg; folic acid $0.0125 \mathrm{mg}$; iron - 25g; copper - 3.75mg; manganese - 12.5mg; zinc $-31.25 \mathrm{mg}$; iodine $-0.25 \mathrm{mg}$; selenium $-0.075 \mathrm{mg}$; excipient q.s.p. $1,000 \mathrm{~g}$.

other studies reported effects on other fatty acids. ENGESETH et al. (1992) observed a decrease in stearic acid and an increase in $\alpha$-linolenic acid and linoleic acid with 20ppm of ractopamine when compared to the control. WIEGAND et al. (2011) observed a reduction of saturated fatty acid (SFA), and an increase in total MUFA. However, no changes in palmitoleic acid, oleic acid, linoleic acid, $\alpha$-linolenic acid, and eicoisenoic acid concentrations when using $7.4 \mathrm{ppm}$ ractopamine compared to the control. Conversely, PERKINS et al. (1992) evaluated the addition of $0,5,10$, and 20ppm of ractopamine, and observed no effect on any of the evaluated fatty acids. COSTA \& SILVA et al. (2017) observed only arachidonic acid alteration in backfat when using ractopamine and suggested that the pigs had already formed an outer layer during the time of ractopamine use; consequently indicating that this technology would have a lesser impact on the backfat lipid profile.

In the meat, nine fatty acids were modified with the inclusion of ractopamine in the diet. Ractopamine addition reduced $(\mathrm{P}<0.05)$ lauric acid and myristic acid concentrations in meat at 20ppm and reduced palmitic acid at $10 \mathrm{ppm}$. However, there was no difference in palmitic acid concentration $(\mathrm{P}<0.05)$ between supplementation with $20 \mathrm{ppm}$ or $10 \mathrm{ppm}$ of ractopamine. Linoleic acid concentration was higher $(\mathrm{P}<0.05)$ after treatment with 10 and $20 \mathrm{ppm}$ of ractopamine than in a diet with $0 \mathrm{ppm}$, while the $\gamma$-linolenic acid, dihomo- $\gamma$-linolenic acid and eicosapentaenoic acid concentrations were higher only with $20 \mathrm{ppm}$ of ractopamine when compared to the others, which were not different from each other $(\mathrm{P}>0.05)$. $\alpha$-Linolenic acid and arachidonic acid 
Table 2 - Lipid profile of backfat and meat from barrows fed with ractopamine levels.

\begin{tabular}{|c|c|c|c|c|c|}
\hline \multirow{2}{*}{ Lipid profile } & \multicolumn{3}{|c|}{--------------Ractopamine, ppm*------------ } & \multirow{2}{*}{$\mathrm{CV}, \%$} & \multirow{2}{*}{ P-value } \\
\hline & 0 & 10 & 20 & & \\
\hline \multicolumn{6}{|c|}{-------------------------------------------------------------------------------'Backfat---------------------------------------------------------------------' } \\
\hline C12:0 (Lauric acid) & 0.08 & 0.08 & 0.08 & 11.74 & 0.34 \\
\hline C14:0 (Myristic acid) & 1.34 & 1.27 & 1.30 & 8.50 & 0.06 \\
\hline C16:0 (Palmitic acid) & 23.51 & 22.81 & 23.39 & 5.13 & 0.08 \\
\hline C16:1 (Palmitoleic acid) & 1.97 & 1.86 & 2.03 & 13.63 & 0.10 \\
\hline C18:0 (Stearic acid) & 10.57 & 10.21 & 10.73 & 9.47 & 0.22 \\
\hline C18:1n9 (Oleic acid) & 39.16 & 39.00 & 40.10 & 4.40 & 0.06 \\
\hline C18:2n6 (Linoleic acid) & 18.63 & 19.37 & 17.62 & 12.30 & 0.07 \\
\hline C18:3n6( $\gamma$-Linolenic acid $)$ & 0.14 & 0.13 & 0.15 & 19.47 & 0.18 \\
\hline $\mathrm{C} 18: 3 \mathrm{n} 3$ ( $\alpha$-Linolenic acid) & $0.94^{\mathrm{AB}}$ & $1.03^{\mathrm{A}}$ & $0.90^{\mathrm{B}}$ & 16.91 & 0.02 \\
\hline C20:3n6 (Dihomo- $\gamma$-Linolenic acid) & 0.11 & 0.11 & 0.10 & 14.12 & 0.84 \\
\hline C20:4n6 (Arachidonic acid) & 0.25 & 0.25 & 0.27 & 16.32 & 0.21 \\
\hline C20:3n3 (Eicosatrienoic acid) & $0.12^{\mathrm{B}}$ & $0.13^{\mathrm{A}}$ & $0.12^{\mathrm{B}}$ & 14.97 & $<0.01$ \\
\hline C20:5n3 (Eicosapentaenoic acid) & 0.02 & 0.02 & 0.01 & 61.44 & 0.87 \\
\hline C22:6n3 (Docosahexaenoic acid) & 0.02 & 0.02 & 0.02 & 36.65 & 0.49 \\
\hline Saturated fatty acids & 37.24 & 36.14 & 37.30 & 5.00 & 0.06 \\
\hline Unsaturated fatty acids & 62.76 & 63.85 & 62.69 & 2.94 & 0.06 \\
\hline Monounsaturated fatty acids & 42.45 & 42.15 & 43.55 & 4.45 & 0.12 \\
\hline Polyunsaturated fatty acids & 20.29 & 21.60 & 19.14 & 12.53 & 0.41 \\
\hline Atherogenic index & 0.46 & 0.44 & 0.46 & 7.76 & 0.06 \\
\hline Thrombogenic index & 1.13 & 1.08 & 1.14 & 8.43 & 0.07 \\
\hline Omega 6: ômega 3 & 17.96 & 17.44 & 18.11 & 7.26 & 0.19 \\
\hline \multicolumn{6}{|c|}{ 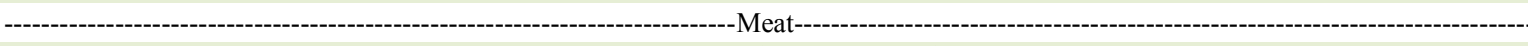 } \\
\hline C12:0 (Lauric acid) & $0.10^{\mathrm{A}}$ & $0.10^{\mathrm{A}}$ & $0.09^{\mathrm{B}}$ & 11.34 & $<0.01$ \\
\hline C14:0 (Myristic acid) & $1.52^{\mathrm{A}}$ & $1.49^{\mathrm{A}}$ & $1.35^{\mathrm{B}}$ & 8.80 & $<0.01$ \\
\hline C16:0 (Palmitic acid) & $26.30^{\mathrm{A}}$ & $25.12^{\mathrm{B}}$ & $25.20^{\mathrm{B}}$ & 4.94 & 0.01 \\
\hline C16:1 (Palmitoleic acid) & 3.24 & 2.99 & 3.02 & 11.94 & 0.13 \\
\hline C18:0 (Stearic acid) & 11.96 & 11.21 & 11.61 & 7.42 & 0.06 \\
\hline C18:1n9 (Oleic acid) & 43.60 & 43.44 & 42.76 & 4.00 & 0.33 \\
\hline C18:2n6 (Linoleic acid) & $9.92^{\mathrm{B}}$ & $12.49^{\mathrm{A}}$ & $12.25^{\mathrm{A}}$ & 18.15 & $<0.01$ \\
\hline C18:3n6( $\gamma$-Linolenic acid $)$ & $0.11^{\mathrm{B}}$ & $0.12^{\mathrm{B}}$ & $0.15^{\mathrm{A}}$ & 23.45 & $<0.01$ \\
\hline C18:3n3 ( $\alpha$-Linolenic acid) & $0.46^{\mathrm{B}}$ & $0.57^{\mathrm{A}}$ & $0.46^{\mathrm{B}}$ & 19.64 & $<0.01$ \\
\hline C20:3n6 (Dihomo- $\gamma$-Linolenic acid) & $0.14^{\mathrm{B}}$ & $0.13^{\mathrm{B}}$ & $0.21^{\mathrm{A}}$ & 29.55 & $<0.01$ \\
\hline C20:4n6 (Arachidonic acid) & $0.06^{\mathrm{B}}$ & $0.08^{\mathrm{A}}$ & $0.05^{\mathrm{B}}$ & 19.88 & $<0.01$ \\
\hline C20:3n3 (Eicosatrienoic acid) & 0.01 & 0.01 & 0.02 & 22.62 & 0.07 \\
\hline C20:5n3 (Eicosapentaenoic acid) & $0.02^{\mathrm{B}}$ & $0.02^{\mathrm{B}}$ & $0.04^{\mathrm{A}}$ & 59.84 & $<0.01$ \\
\hline C22:6n3 (Docosahexaenoic acid) & 0.03 & 0.03 & 0.04 & 60.09 & 0.09 \\
\hline Saturated fatty acids & $40.80^{\mathrm{A}}$ & $39.07^{\mathrm{B}}$ & $39.61^{\mathrm{AB}}$ & 3.87 & 0.01 \\
\hline Unsaturated fatty acids & $59.20^{\mathrm{B}}$ & $60.93^{\mathrm{A}}$ & $60.39^{\mathrm{AB}}$ & 2.56 & 0.01 \\
\hline Monounsaturated fatty acids & 47.20 & 47.37 & 46.91 & 4.45 & 0.19 \\
\hline Polyunsaturated fatty acids & $10.83^{\mathrm{B}}$ & $13.59^{\mathrm{A}}$ & $13.41^{\mathrm{A}}$ & 17.73 & $<0.01$ \\
\hline Atherogenic index & $0.55^{\mathrm{A}}$ & $0.51^{\mathrm{B}}$ & $0.51^{\mathrm{B}}$ & 7.39 & $<0.01$ \\
\hline Thrombogenic index & $1.35^{\mathrm{A}}$ & $1.24^{\mathrm{B}}$ & $1.27^{\mathrm{B}}$ & 7.00 & $<0.01$ \\
\hline Omega 6: ômega 3 & $22.03^{\mathrm{AB}}$ & $19.78^{\mathrm{B}}$ & $23.76^{\mathrm{A}}$ & 13.73 & $<0.01$ \\
\hline
\end{tabular}

${ }^{*}$ Means followed by different letters are statistically different from each other $(\mathrm{P}<0.05)$ by Tukey test.

values were higher $(\mathrm{P}<0.05)$ after the addition of $10 \mathrm{ppm}$ of ractopamine and lower with 0 and 20ppm, which did not differ from each other $(\mathrm{P}>0.05)$. APPLE et al. (2007) performed a meta-analysis and reported that $20 \mathrm{ppm}$ of ractopamine must be used in diets to observe changes in meat fatty acid composition. However, this study showed that $10 \mathrm{ppm}$ would be enough to change some of the fatty acids in the meat. 
Others have also observed changes in fatty acid concentrations when adding lower ractopamine concentrations to the diet. For example, ENGESETH et al. (1992) studied 0 and 10ppm of ractopamine and observed increased concentrations of the fatty acids palmitoleic acid, oleic acid, and $\alpha$-linolenic acid, as well as decreased concentrations in other unidentified fatty acids. PERKINS et al. (1992) studied 20ppm of ractopamine and observed a linear effect with an increase only in linoleic acid in the backfat. WATANABE et al. (2012) did not find significant differences in the Longissimus dorsi lipid profiles from pigs fed four concentrations of ractopamine.

Ractopamine may affect meat fatty acids because it modifies fatty acid proportions. However, it could be considered that this effect would be secondary, with its main effect being to modify the amount of intramuscular fat. Although, the review by APPLE et al. (2007) indicates that ractopamine does not modify the amount of fat when analyzed by a subjective evaluation by score, some studies have shown a change in the amount of meat fat when analyzed via lipid extraction (AALHUS et al., 1990; CARR et al. al., 2005). Therefore, it could be inferred that ractopamine alters the amount of intramuscular fat and; consequently, the fat's lipid profile.

Adding ractopamine to the diet increased PUFA concentrations in the meat $(\mathrm{P}<0.05)$; however, PUFA concentrations obtained after adding 10 and $20 \mathrm{ppm}$ of ractopamine were not statistically different. In contrast, the opposite effect was observed for AI and TI, which were reduced with $10 \mathrm{ppm}$ of ractopamine $(\mathrm{P}<0.05)$. The SFA concentration decreased when $10 \mathrm{ppm}$ of ractopamine was used and presented an intermediate value when $20 \mathrm{ppm}$ was used. The UFA concentration increased with $10 \mathrm{ppm}$ of ractopamine and presented an intermediate value with $20 \mathrm{ppm}$.

A relationship between SFA intake with the increase of heart diseases has been established (BHUPATHIRAJU \& TUCKER, 2011) and PUFA intake has been shown to be inversely associated with coronary heart disease risk (JAKOBSEN et al., 2009). Therefore, the ractopamine-induced SFA decrease has beneficial effect on meat fat for providing health benefits to consumers.

This effect of ractopamine may be related to the age of the animals, because $40 \mathrm{~kg}$ pigs fed with the same diet for 20,60, and 100 days showed increased stearic acid and oleic acid proportions and a reduced linoleic acid proportion (KOUBA et al., 2003). The increase of animal fat during growth is strongly linked to de novo lipid synthesis, which increases MUFA and SFA production.
De novo lipid synthesis occurs from substrates of oil-free or low-oil diets, which synthesize SFAs and MUFAs with a double bond in position 9 are synthetized (DURAN-MONTGÉ et al., 2010). The use of ractopamine decreases lipogenesis (MILLS et al., 1990), which reduces SFA and MUFA production and; consequently, increases PUFA deposition. This relationship was seen in meat during this study, where concentrations of the PUFAs linoleic acid, $\gamma$-linolenic acid, and dihomo- $\gamma$-linolenic acid increased with the use of ractopamine, while concentrations of the SFAs lauric acid, myristic acid, and palmitic acid decreased.

In this study, ractopamine use altered the meat lipid profile to be healthier for consumers, especially due to increased linoleic acid and PUFA concentrations, and decreased lauric acid, myristic acid and palmitic acid concentrations, which are included in the AI and TI indexes. Consequently, the AI and TI indexes, which are positively correlated with the occurrence of cardiovascular disease, also decreased (ULBRICHT \& SOUTHGATE, 1991). Results indicated that $10 \mathrm{ppm}$ of ractopamine was sufficient to change some fatty acids.

The omega 6:omega 3 ratio showed no significant difference in backfat with or without ractopamine addition ( $\mathrm{P}>0.05)$; however, in the meat, the ratio decreased with $10 \mathrm{ppm}$ and increased with $20 \mathrm{ppm}$ of ractopamine, while intermediate values were recorded with 0 ppm. All omega 6: omega 3 values reported in backfat and meat fat were much higher than the recommended (4:1) for human consumption (SCOLLAN et al., 2006). The value reported when using 10ppm (20:1) was the lowest and closest to the recommended ratio. Although, all values are high, they were close to other values seen in the literature (WEBER et al., 2006; WATANABE et al., 2012).

Although, a high PUFA concentration is beneficial, it is important to consider the omega 6:omega 3 ratio as it indicates the quality of PUFAs. That ratio should be kept below of $4: 1$, because omega 6 fatty acids are related to pro-inflammatory immune responses, which may be related to cardiac problems even though omega 6 fatty acids are polyunsaturated (CALDER, 2006).

\section{CONCLUSION}

Ractopamine affects the concentration of more fatty acids in the meat than in the backfat, modifying nine fatty acids in meat fat and only two fatty acids in backfat. Ten ppm of ractopamine results in meat with healthier fat by providing higher 
concentrations of PUFAs, such as linoleic acid, $\gamma$-linolenic acid, $\alpha$-linolenic acid, and arachidonic acid, and lower concentrations of palmitic acid, SFAs, AI, TI and the omega 6: omega 3 ratio.

\section{BIOETHICS AND BIOSSECURITY COMMITTEE APPROVAL}

The Ethics Committee for the Use of Animals of Universidade Federal do Mato Grosso do Sul (UFMS), under protocol $\mathrm{n}^{\circ} 429 / 2012$, approved this project.

\section{ACKNOWLEDGMENTS}

The Foundation to Support the Development of Education, Science and Technology of the State of Mato Grosso do Sul (FUNDECT) for the scholarship.

\section{CONFLICTS OF INTEREST}

The authors declare no conflict of interest. The founding sponsors had no role in the design of the study; in the collection, analyses, or interpretation of data; in the writing of the manuscript, and in the decision to publish the results.

\section{REFERENCES}

AALHUS, J.L. et al. The effect of ractopamine on performance, carcass composition and meat quality of finishing pigs. Canadian Journal of Animal Science, v.70, n.3, p.943-952, 1990. Available from: <http://www.nrcresearchpress.com/doi/pdf/10.4141/cjas90113>. Accessed: Mar. 26, 2018. doi: 10.4141/cjas90-113.

APPLE, J.K. et al. Meta-Analysis of the Ractopamine Response in Finishing Swine. The Professional Animal Scientist, v.23, n.3, p.179-196, 2007. Available from: <http://www.sciencedirect. com/science/article/pii/S1080744615309645>. Accessed: Jan. 15, 2017. doi: 10.15232/S1080-7446(15)30964-5.

BHUPATHIRAJU, S.N.; TUCKER, K.L. Coronary heart disease prevention: Nutrients, foods, and dietary patterns. Clinica Chimica Acta, v.412, n.17, p.1493-1514, 2011. Available from: $<$ https://www. ncbi.nlm.nih.gov/pubmed/21575619>. Accessed: Sept. 23, 2017. doi: 10.1016/j.cca.2011.04.038.

BRUMATTI, R.C.; KIEFER, C. Technical-economic simulation of ractopamine inclusion in diets for finishing pigs. Arquivos Brasileiros de Medicina Veterinária e Zootecnia, v.62, n.1, p.163-171, 2010. Available from: <http://www.scielo.br/pdf/abmvz/v62 n1/v62n1a22.pdf>. Accessed: Sept. 03, 2017. doi: 10.1590/S0102-09352010000100022.

CANTARELLI, V.S. et al. Carcass characteristics and economic viability of the use of ractopamine for finishing swine with ad libitum or restricted feeding. Ciência Rural, v.39, n.3, p.833-851, 2009. Available from: <http://www.scielo.br/pdf/cr/v39 n3/a32v39n3.pdf >. Accessed: Nov. 01, 2017. doi: 10.1590/S0103-84782009000300032.

CALDER, P.C. Polyunsaturated fatty acids and inflammation. Prostaglandins, Leukotrienes and Essential Fatty Acids, v.75, n.3, p.197-202, 2006. Available from: <https://www.ncbi.n lm.nih. gov/pubmed/15787620>. Accessed: Oct. 09, 2017. doi: 10.1042/ BST0330423.
CARR, S.N. et al. Effects of different cereal grains and ractopamine hydrochloride on performance, carcass characteristics, and fat quality in late-finishing pigs. Journal of Animal Science, v. 83, p. 223-230, 2005. Available from: $<$ https://www.ncbi.nlm.nih.gov/pubmed/15 583063>. Accessed: May. 13, 2017. doi: 10.2527/2005.831223x.

CORASSA, A. et al. Performance, carcass characteristics and bone composition of swines feddifferent levels of ractopamine and phytase. Revista Brasileira de Zootecnia, v.39, n.8, p.1740-1747, 2010. Available from: $<$ http://www.scielo.br/pdf/rbz/v39n8/v39n8a16.pdf $>$. Accessed: Feb. 16, 2017. doi: 10.1590/S1516-35982010000800016.

COSTA E SILVA, L.C. et al. Effects of ractopamine hydrochloride and immunological castration in pigs. Part 2: belly quality characteristics and fatty acid composition. Food Science and Technology, v.37, n.3, p.404-410, 2017. Available from: <http://www.scielo.br/pdf/ cta/v37n3/0101-2061-cta-1678-457X12716.pdf >. Accessed: Feb. 21, 2017. doi: 10.1590/1678-457x.12716.

DURAN-MONTGÉ, P. et al. De novo fatty acid synthesis and balance of fatty acids of pigs fed different fat sources. Livestock Science, v.132, n.1, p.157-164, 2010. Available from: $<$ http://www.sciencedirect.com/science/article/pii/S1871141310002064>. Accessed: Mar. 26, 2017. doi: 10.1016/j.livsci.2010.05.017.

ENGESETH, N.J. et al. Fatty acid profiles of lipid depots and cholesterol concentration in muscle tissue of finishing pigs fed ractopamine. Journal of Food Science, v.57, 1992. Available from: $<$ https://doi. org/10.1111/j.1365-2621.1992.tb11262.x>. Accessed: Mar. 26, 2018. doi: $10.1111 /$ j.1365-2621.1992.tb11262.x.

FERREIRA, M.S.S. et al. Effect of ractopamine on lipid metabolism in vivo - a systematic review. Brazilian Archives of Biology and Technology, v.56, n.1, p.35-43, 2013. Available from: <http:// www.scielo.br/pdf/babt/v56n1/05.pdf>. Accessed: Jun. 07, 2017. doi: 10.1590/S1516-89132013000100005.

GOIS, F.D. et al. Dietary Brazilian red pepper essential oil on pork meat quality and lipid oxidation. Ciência Rural, v.47, n.2, 2017. Available from: <http://www.scielo.br/pdf/cr/v47n2/16784596-cr-47-02-20160127.pdf>. Accessed: Oct. 02, 2017. doi: $10.1590 / 0103-8478 \mathrm{cr} 20160127$.

HARA, A.; RADIN, N.S. Lipid extraction of tissues with low-toxicity solvent. Analytical Biochemistry, v.90, n.1, p.420-426, 1978. Available from: $<$ http://dx.doi.org/10.1016/0003-2697(78)90046-5>. Accessed: Apr. 28, 2017. doi: 10.1016/0003-2697(78)90046-5.

JAKOBSEN, M.U. et al. Major types of dietary fat and risk of coronary heart disease: a pooled analysis of 11 cohort studies. The American Journal of Clinical Nutrition, v. 89, n.5, p.1425-1432, 2009. Available from: $<$ http://ajcn.nutrition.org/content/89/5/1425. long>. Accessed: Sept. 06, 2017. doi: 10.3945/ajcn.2008.27124.

KIEFER, C.; SANCHES, J.F. Meta-analysis of the ractopamine levels in diets for finishing pigs. Revista Brasileira de Zootecnia, v.38, n.6, p.1037-1044, 2009. Available from: <http://www.scielo. br/pdf/rbz/v38n6/v38n6a10.pdf >. Accessed: Oct. 05, 2017. doi: 10.1590/S1516-35982009000600010.

KIM, J.S. et al. Impact of dietary fat sources and feeding level on adipose tissue fatty acids composition and lipid metabolism related gene expression in finisher pigs. Animal Feed Science and Technology, v.196, p.60-67, 2014. Available from: <http://www.sciencedirect.com/science/article/pii/S037784011400193X>. Accessed: Jun. 04, 2017. doi: 10.1016/j.anifeedsci.2014.06.007. 
KOUBA, M. et al. Effect of a high linolenic acid diet on lipogenic enzyme activities, fatty acid composition, and meat quality in the growing pig. Journal of Animal Science, v.81, n.8, p.1967-1979, 2003. Available from: <https://www.ncbi.nlm.nih.gov/pubmed/12926779>. Accessed: Jul. 11, 2017. doi: 10.2527/2003.8181967x.

MILLS, S.E. et al. Effects of ractopamine on adipose tissue metabolism and insulin binding in finishing hogs. Interaction with genotype and slaughter weight. Domestic Animal Endocrinology, v.7, n.2, p.251264, 1990. Available from: $<$ https://www.sciencedirect.com/science/article/pii/073972409090031T?via\%3Dihub>. Accessed: Mar. 26, 2018. doi: 10.1016/0739-7240(90)90031-T.

ROSTAGNO, H. S. et al. Tabelas brasileiras para aves e suínos: composição de alimentos e exigências nutricionais. 3. ed. Viçosa: Editora UFV. 2011. 252p.

SCOLLAN, N.D. et al. Innovations in beef production systems that enhance the nutritional and health value of beef lipids and their relationship with meat quality. Meat Science, v.74, n.1, p.17-33, 2006. Available from: <https://www.ncbi.nlm.nih.gov/pubmed/22062713>. Accessed: Mar. 09, 2017. doi: 10.1016/j.meatsci.2006.05.002.
ULBRICHT, T.L.V.; SOUTHGATE, D.A.T. Coronary heart disease: Seven dietary factors. Lancet, v.338, n.8773, p.985-992, 1991. Available from: <http://dx.doi.org/10.1016/0140-6736(91)91846-M>. Accessed: Aug. 28, 2016. doi: 10.1016/0140-6736(91)91846-M

WATANABE, P.H. et al. Meat quality of gilts fed different ractopamine concentrations in diet. Arquivos Brasileiros de Medicina Veterinária e Zootecnia, v.64, n.5, p.1381-1388, 2012. Available from: <http://www.scielo.br/pdf/abmvz/v 64n5/v64n5a40.pdf $>$. Accessed: Aug. 14, 2016. doi: 10.1590/S0102-09352012000500040.

WEBER, T.E. et al. Evaluation of the effects of dietary fat, conjugated linoleic acid, and ractopamine on growth performance, pork quality, and fatty acid profiles in genetically lean gilts. Journal of Animal Science, v.84, p.720-732, 2006. Available from: <https://www.ncbi.nlm.nih.gov/ pubmed/16478965>.Accessed: Sept. 20,2016. doi: 10.2527/2006.843720x.

WIEGAND, B.R. et al. Fatty acid profiles and iodine values correlations between 4 carcass fat depots from pigs fed varied combinations of ractopamine and energy. Journal of Animal Science, v. 89, p. 3580-3586, 2011. Available from: <https://dx.doi.org/10.2527/ jas.2010-3303 >. Accessed: Jan. 23, 2016. doi: 10.2527/jas.2010-3303. 